\title{
EFFECT OF INJECTION TIMING ON PERFORMANCE AND EMISSION CHARACTERISTICS OF PALM BIODIESEL AND DIESEL BLENDS
}

PRABHU APPAVU*; JAYAPRABAKAR, $\mathrm{J}^{\star *}$; BEEMKUMAR, $\mathrm{N}^{* *}$ and YUVARAJAN DEVARAJAN*

\begin{abstract}
Injection timing is a vital factor which governs the emissions and performance characteristics of the engine. This work portrays the effect of injection timing (IT) on cerium oxide nano particle doped palm biodiesel (20\% vol) and diesel ( $80 \% \mathrm{vol})$ blends. Palm biodiesel is found to be a promising alternative to the petroleum diesel fuel owing to their similarity in physical and chemical properties. Addition of cerium oxide nano particle is carried out at $30 \mathrm{ppm}, 60 \mathrm{ppm}$ and $90 \mathrm{ppm}$. The modified fuels are introduced in reducing injection timing of $19^{\circ}, 21^{\circ}$ and $23^{\circ} \mathrm{bTDC}$. A four-stroke, vertical, air-cooled, single cylinder, diesel engine is employed in this study. The performance characteristics (BSFC, BTE) improved for fuel blends at $I T=23^{\circ} \mathrm{bTDC}$. Further, results also revealed a significant reduction in emissions $\mathrm{CO}, \mathrm{NO}_{\mathrm{X}}, \mathrm{HC}$ emissions at $I T=23^{\circ} \mathrm{bTDC}$.
\end{abstract}

Keywords: palm biodiesel, cerium oxide nano particle, performance, exhaust emissions.

Date received: 4 February 2018; Sent for revision: 24 February 2018; Received in final form: 21 March 2018; Accepted: 25 July 2018.

\section{INTRODUCTION}

Increasing energy demand and restructured emission norms pave the way the search for a promising alternative such as biofuels for engine applications. By utilising biofuels, the gap between demand and energy source is reduced significantly (Devarajan et al., 2016). Biodiesels are biodegradable, readily available, portable, and renewable in nature (Devarajan et al., 2017a). Biodiesel is obtained from a variety of natural feedstock sources providing possible starting materials for biodiesel production (Devarajan et al., 2017b). A variety of non-edible seeds such as neem, jatropha, pongamia, mahua, and castor are employed to obtain the biodiesel.

* Department of Mechanical Engineering, Vel Tech Rangarajan Dr Sagunthala R\&D Institute of Science and Technology, 60062 Chennai, Tamil Nadu, India.

E-mail: dyuvarajan2@gmail.com

** Department of Mechanical Engineering, Sathyabama Institute of Science and Technology, 600119 Chennai, Tamil Nadu, India.
Non-edible oil plants are distinguished from a second-generation feedstock which is economical and is cultivated across the globe. Vegetable oils require a chemical process called transesterification to reduce its fatty acid contents (Murugesan $e t$ al., 2013). After transesterification, vegetable oils can be blended with diesel or can also be used as a neat fuel in diesel with no or minor modifications.

Many research works have found that appending nano-sized metallic particle at different proportions to biodiesel can reduce its emissions (Pandian et al., 2017). The $\mathrm{CeO}_{2}, \mathrm{NiO}, \mathrm{MnO}, \mathrm{ZnO}$ and $\mathrm{CuO}$ have commonly used metal oxides. Metal oxide nanoparticle improves the rate of evaporation of fuels, reduces the delay period and lowers the emissions of biodiesel. Pandian et al. (2017) scrutinised the impact of $\mathrm{TiO}_{2}$ nano metals and reported significant improvement in its chemical properties. In addition, $4 \%$ of $\mathrm{NO}_{x}$ emissions were reduced below that of diesel. Sajeevan et al. (2016) reviewed the effects of nano metals as an additive in biodiesel-fueled engines. They reported that nano 
metal acts as an oxidation buffer and reduces the $\mathrm{NO}_{\mathrm{x}}$ emissions in the range between $2.1 \%$ and $6.7 \%$. Ravichandra Ganesh and Hemachandra Reddy (2015) scrutinised the emission impact of $\mathrm{CeO}_{2}$ in biodiesel. They found that by incorporating of $\mathrm{CeO}_{2}$ in neat biodiesel, $\mathrm{NO}_{x}$ emissions were reduced by $3.7 \%$ and $4.4 \%$, respectively. From the survey of the literature, it has been experimentally found that by appending metal oxide nano particle to diesel and biodiesel blends, the $\mathrm{NO}_{x}$ emissions are reduced and the combustion improves. Hence, this work aims to investigate the effect of appending $\mathrm{CeO}_{2}$ nano particle in the powder form at 30,60 and 90 ppm to palm biodiesel and diesel blends. In addition, the effect of injection timing (IT) on the cerium oxide nano particle doped palm biodiesel $(20 \% \mathrm{vol})$ and diesel $(80 \% \mathrm{vol})$ blends (BD20) is also investigated and compared with diesel.

\section{MATERIALS AND METHODS}

\section{Preparation of Palm Biodiesel}

Palm oil biodiesel was extracted from the neat palm oil through the alkali-based transesterification process. A solution containing $47.5 \mathrm{ml}$ of methanol and $2.5 \mathrm{ml}$ of catalysts (sodium hydroxide) is mixed with $600 \mathrm{ml}$ of palm oil. The mixture is heated to $80^{\circ} \mathrm{C}$ for $60 \mathrm{~min}$ at constant agitation. The mixture was then undisturbed to obtain neat biodiesel and methanol. The methanol in the mixture was then removed by reheating $90^{\circ} \mathrm{C}$. Cerium oxide nano particles in the nano powder form $\left(\mathrm{CeO}_{2}\right.$, alpha, $98+\%, 50 \mathrm{~nm}$ ) were mixed with BD20 at different dosage levels of 30, 60 and 90 ppm by mass basis. Table 1 shows the properties of cerium oxide nano particles. Ultrasonicator with a frequency of 60-100 $\mathrm{kHz}$ is employed to ensure a homogenous emulsion.

TABLE 1. PROPERTIES OF CERIUM OXIDE NANO PARTICLES

\begin{tabular}{cc}
\hline Molecular formula & $\mathrm{CeO}_{2}$ \\
Molecular weight & $81.12 \mathrm{~g} \mathrm{~mol}^{-1}$ \\
Average particle size & $60 \mathrm{~nm}$ \\
Form & Powder \\
Colour & Pure white \\
\hline
\end{tabular}

Fuel containing $\mathrm{CeO}_{2}$ nano particle is further mixed and stirred with surfactant (Span-80) using a magnetic agitator for $60 \mathrm{~min}$ at a speed of $510 \mathrm{rpm}$ in atmospheric conditions to improve the bonding between nanoparticle and fuel. Table 2 shows the properties of the modified fuels and diesel.

\section{Experimental Set-up}

Research type $4.4 \mathrm{~kW}$ immobile engine $($ compression ratio $=16.5: 1$; speed $=1600 \mathrm{rpm}$; cylinder $=1$ ) fuelling the biodiesel (methyl ester) is employed in this work. Table 3 shows the specification of the engine. Eddy current dynamometer is used in the work. The schematic layout of engine setup is shown in Figure 1. The engine exhausts are measured by AVL Ditest gas 1000 exhaust gas analyser. Chromel K-Type thermocouple was used for measuring the exhaust gas temperature.

\section{RESULTS AND DISCUSSION}

The analysis is carried out with diesel, BD20 and nano particle additive to BD20 in $30 \mathrm{ppm}, 60 \mathrm{ppm}$ and $90 \mathrm{ppm}$ and injected at $23^{\circ} \mathrm{bTDC}$ and 200 bar. Modified biodiesels are injected into the engine at $240 \mathrm{bar}$ pressure and the IT is varied between $19^{\circ}$ and $21^{\circ} \mathrm{bTDC}$ for comparison.

\section{Brake Thermal Efficiency (BTE)}

Figures $2 a, 2 b$ and $2 c$ show the variations in BTE for palm biodiesel and diesel blends (BD20) doped with different proportions of $\mathrm{CeO}_{2}$ nanoparticles. BTE of the biodiesel is less than diesel at all loads (Murugesan et al., 2013). This is due to the higher calorific value of diesel. BTE of test fuels increases with the load. At higher loads, conversion of fuel into useful work is higher causing higher BTE. In addition, $\mathrm{CeO}_{2}$ nano particle improved BTE of tested fuels. The $\mathrm{CeO}_{2}$ buffers oxygen and improve BTE (Naik and Balakrishna, 2017; Pandian et al., 2017). This is due to the catalytic activity of $\mathrm{CeO}_{2}$ nano particle which aids the improved combustion (Pandian et al., 2017). Further, the $\mathrm{CeO}_{2}$ nano particle provides surplus oxygen during combustion which in turn promotes the oxidation reaction

TABLE 2. PROPERTIES OF THE PALM BIODIESEL AND DIESEL BLENDS

\begin{tabular}{llllll}
\hline & Diesel & BD20 & BD20+30 $\mathbf{~ p m ~}$ & BD20+60 ppm & BD20+90 $\mathbf{~ p p m}$ \\
\hline $\begin{array}{l}\text { Kinematic viscosity } \\
\quad \text { @40 } 0^{\circ} \mathrm{C} \text { in cSt }\end{array}$ & 2.4 & 3.47 & 3.58 & 3.83 & 3.97 \\
Flash point $\left({ }^{\circ} \mathrm{C}\right)$ & 46 & 49 & 52 & 63 & 75 \\
Fire point $\left({ }^{\circ} \mathrm{C}\right)$ & 55 & 60 & 65 & 76 & 87 \\
Calorific value $\left(\mathrm{kJ} \mathrm{kg}^{-1}\right)$ & 42534 & 41342 & 41402 & 41514 & 41608 \\
Density @15 $5^{\circ} \mathrm{C}$ in kg m${ }^{-3}$ & 835 & 858 & 862 & 865 & 869 \\
\hline
\end{tabular}




\section{TABLE 3. SPECIFICATION OF THE ENGINE}

\begin{tabular}{ll}
\hline 1. Type & 2. Four stroke \\
3. Stroke & 4. $110 \mathrm{~mm}$ \\
5. Bore & 6. $88 \mathrm{~mm}$ \\
7. Rated output & 8. $4.4 \mathrm{~kW}$ \\
9. Rated speed & 10. $1600 \mathrm{rpm}$ \\
11. Injection timing $\left({ }^{\circ} \mathrm{bTDC}\right)$ & 12. $19-23$ \\
13. Compression ratio & 14. 16.5 \\
15. Loading device & 16. Electric generator \\
17. Injection pressure & 18. $200 \mathrm{bar}$ \\
19. Fuel pump plunger diameter & 20. $8 \mathrm{~mm}$ \\
21. Number of injector nozzle & 22. 4 \\
23. Diameter of injector nozzle & 24. $0.32 \mathrm{~mm}$ \\
25. Cooling & 26. Air cooled \\
27. Position & 28. Vertical \\
29. Dynamometer constant & 30. 2000 \\
31. Supply voltage & 32. $240 \pm 10 \% \mathrm{AC}, 50 \mathrm{~Hz}, 1 \Phi$ \\
33. Maximum excitation current & 34. 6 to $8 \mathrm{Amp}$ \\
\hline
\end{tabular}

(Pandian et al., 2017). Significant improvement in BTE is observed at $23^{\circ} \mathrm{CA}$ bTDC. At retard IT $\left(23^{\circ} \mathrm{CA} \mathrm{bTDC}\right)$, there is the lesser quantity of fuel admittance which improves the atomisation process and combustion process and results in higher BTE. This result is in line with much other research works carried for nano particle additives with biodiesel (Sabari et al., 2018; Karthikeyan and Jayaprabakar, 2017). At full load conditions, BTE for biodiesel and diesel blends are lower than diesel. However, by adding $\mathrm{CeO}_{2}$ nano particle at $30 \mathrm{ppm}, 60 \mathrm{ppm}$ and 90 ppm, a marginal increase in BTE are observed for biodiesel and diesel blends.

\section{Brake Specific Fuel Consumption (BSFC)}

Figures $3 a, 3 b$ and $3 c$ show the variations in BSFC for palm biodiesel and diesel blends (BD20) doped with different proportions of $\mathrm{CeO}_{2}$ nano particles. BSFC of the biodiesel and diesel blends is more than diesel at all loads (Raj Bukkarapu et al., 2017). BSFC of test fuels decreases with the load. In addition, $\mathrm{CeO}_{2}$ nano particle improved BSFC for biodiesel and diesel blends. The $\mathrm{CeO}_{2}$ nano particle buffers oxygen and improve BSFC (Pandian et al., 2017). Significant reduction in BSFC is observed at $23^{\circ}$ CA bTDC. At retard IT $\left(23^{\circ} \mathrm{CA}\right.$ bTDC), there is the lesser quantity of fuel admittance which improves the atomisation process and combustion process and results in lower BSFC. At full load conditions, BSFC for biodiesel and diesel blends is higher than diesel. However, by adding $\mathrm{CeO}_{2}$ nano particle at 30 ppm, 60 ppm and 90 ppm, a marginal decrease in BSFC are observed for biodiesel and diesel blends. This result is in line with much other research works carried for nano particle additives with biodiesel (Jayaprabakar et al., 2015; Sabari et al., 2018).

\section{Unburned Hydrocarbon (HC) Emissions}

Figures $4 a, 4 b$, and $4 c$ show the variations in $\mathrm{HC}$ emission for palm biodiesel and diesel blends (BD20) doped with different proportions of $\mathrm{CeO}_{2}$ nano particles. HC emissions from biodiesel and diesel blends are less than diesel at all loads (Venkata Ramanan and Yuvarajan, 2016). HC emissions for

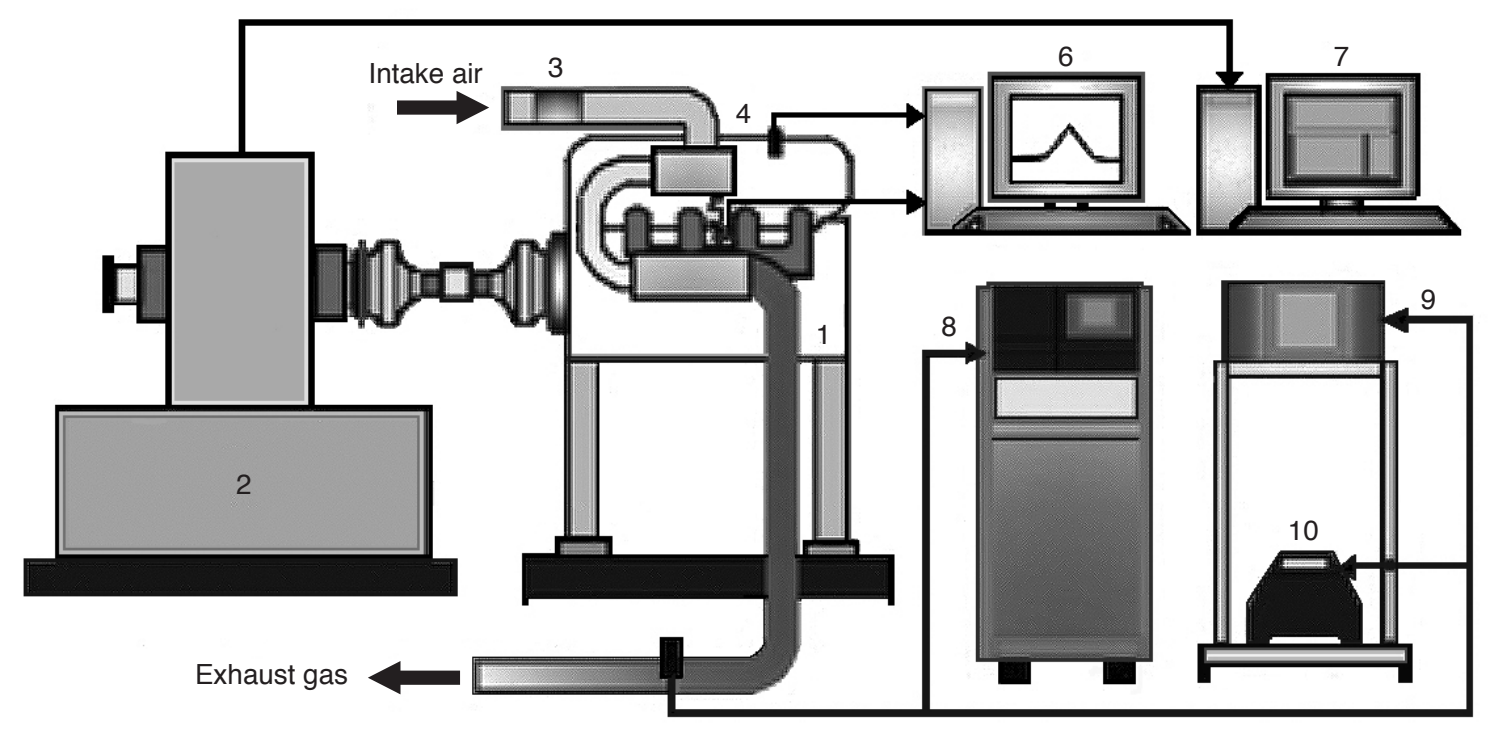
1. Test engine
2. Eddy current dynamometer
3. Air mass sensor
4. Pressure sensor
5. Accelerometer

6. Data aquisition system (DAS)

7. Dynamometer controller

8. Bosch gas analyser

9. AVL digas analyser

10. Smoke opacity meter

Figure 1. The schematic layout of engine set-up. 
(a)

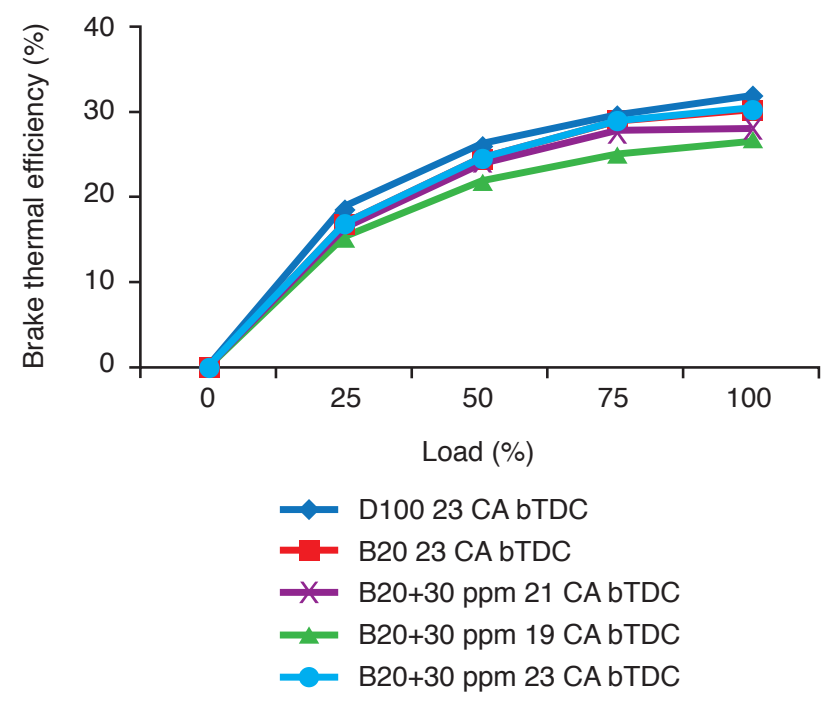

(b)

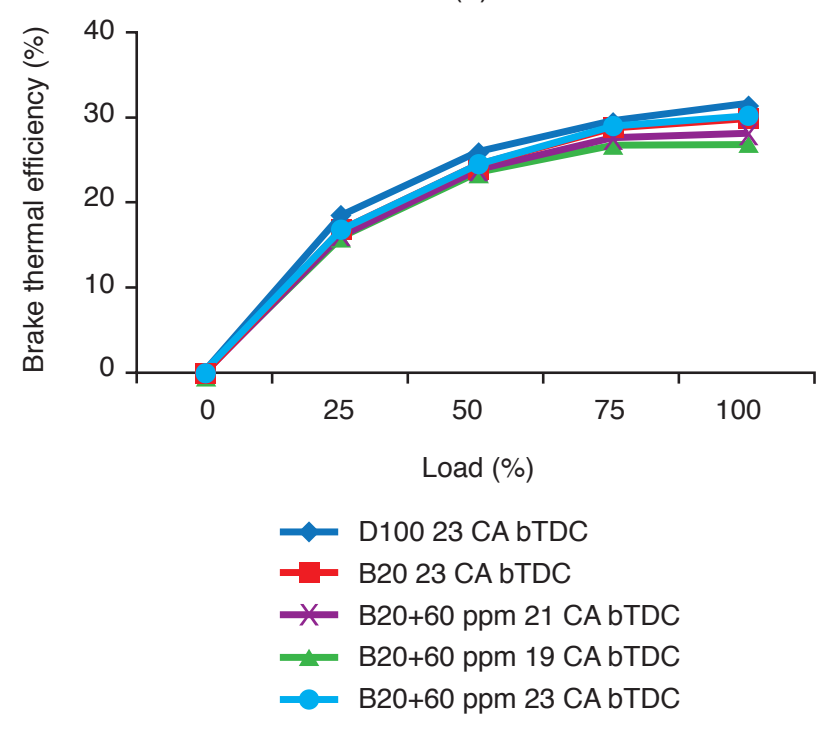

(c)

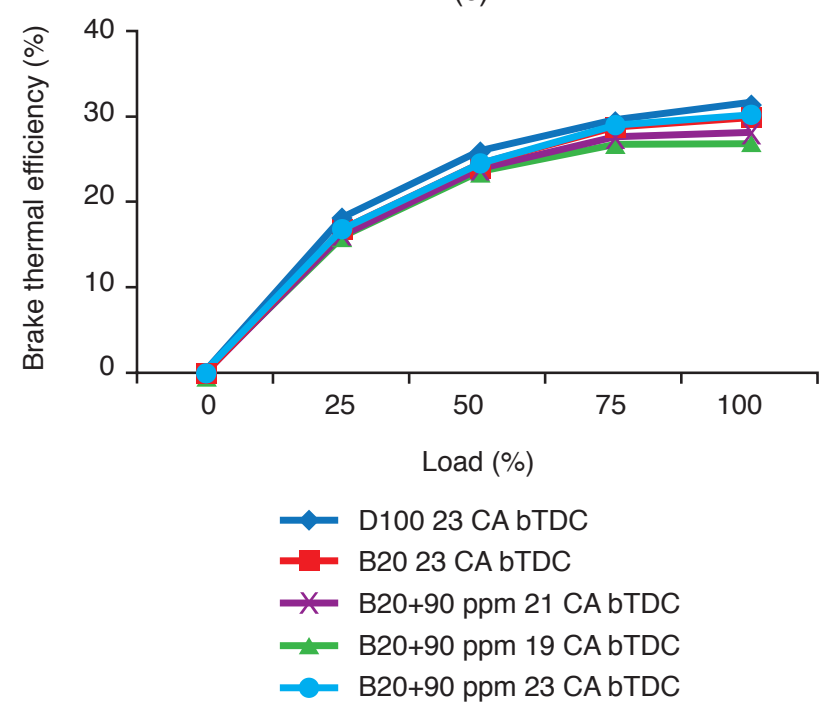

Figure 2. Brake thermal efficiency (BTE) of palm biodiesel and diesel blends at different working conditions $(a, b, c)$. (a)

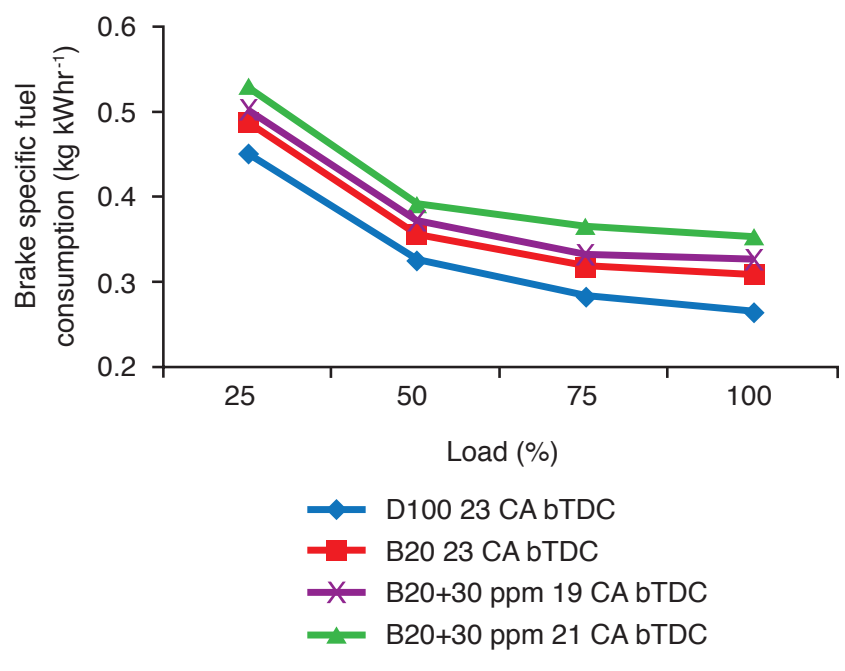

(b)

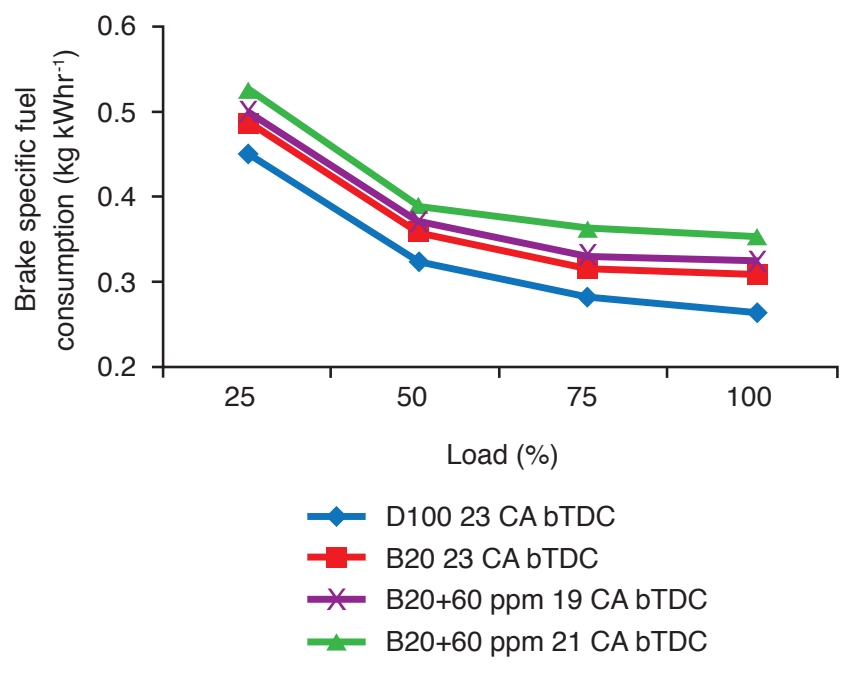

(c)

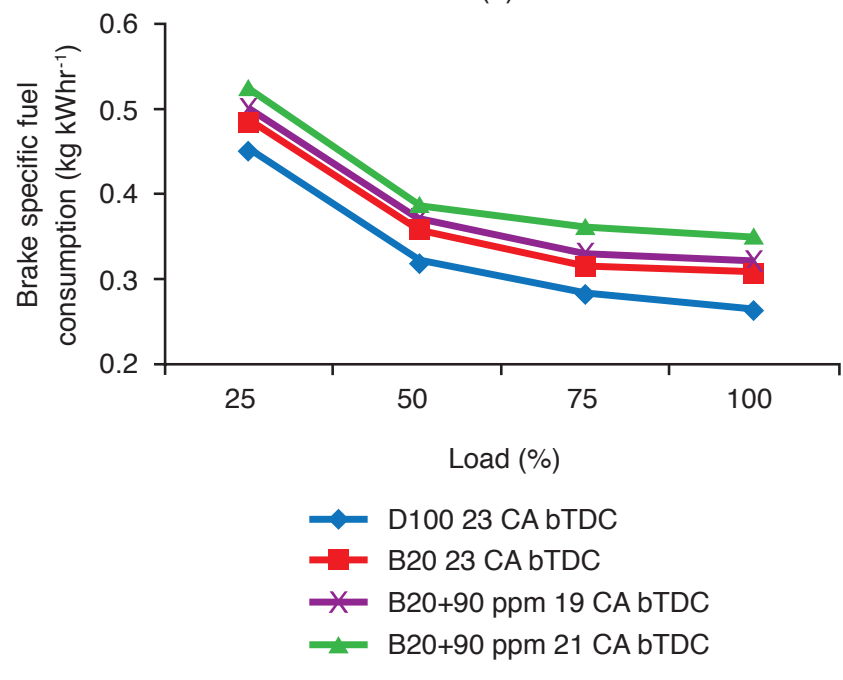

Figure 3. Brake specific fuel consumption (BSFC) of palm biodiesel and diesel blends at different working conditions $(a, b, c)$. 
(a)

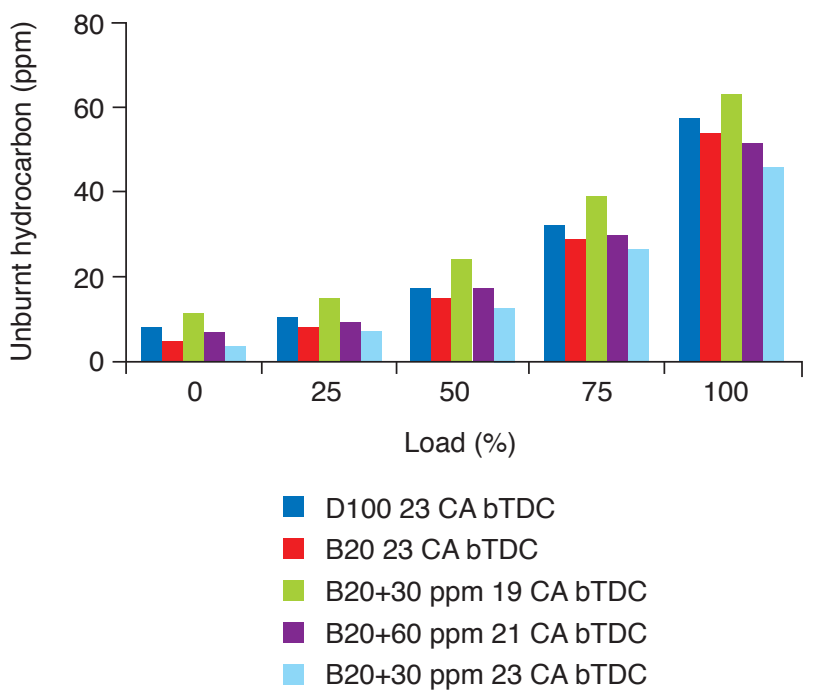

(b)

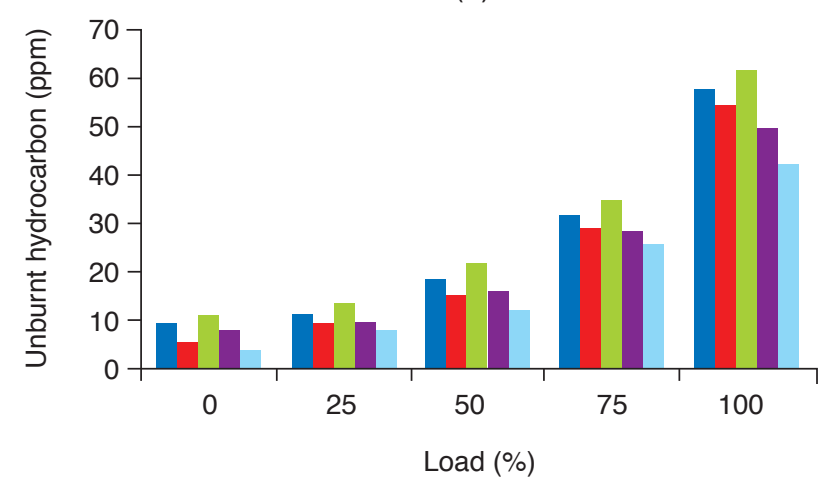

D100 23 CA bTDC
B20 23 CA bTDC
B20+60 ppm 19 CA bTDC
B20+60 ppm 21 CA bTDC
B20+60 ppm 23 CA bTDC

(c)

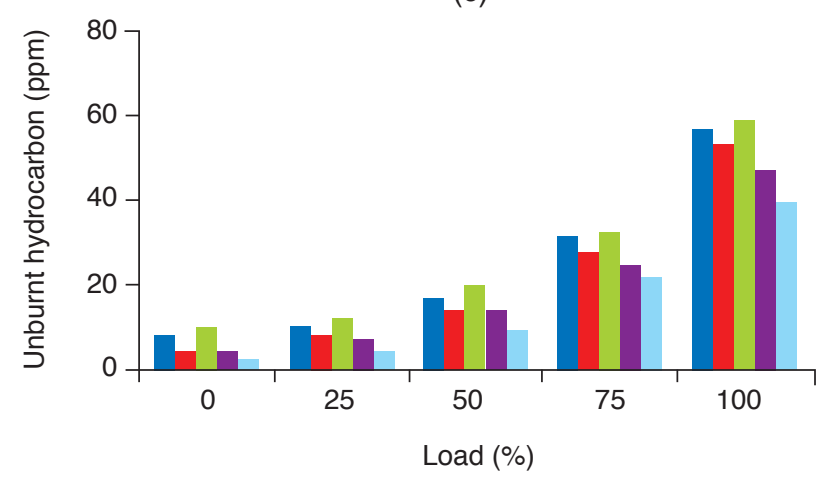

D100 23 CA bTDC

- B20 23 CA bTDC

- B20+90 ppm 19 CA bTDC

- B20+90 ppm 21 CA bTDC

- B20+90 ppm 23 CA bTDC

Figure 4. Hydrocarbon (HC) emissions of palm biodiesel and diesel blends at different working conditions $(a, b, c)$. all fuels increase with the load. At higher loads, the mixture becomes too rich causing higher $\mathrm{HC}$ emissions. Addition of $\mathrm{CeO}_{2}$ nano particle improved the combustion of fuels by supplying additional oxygen during combustion (Ravichandra Ganesh and Hemachandra Reddy, 2015). The $15 \%$ to $26 \%$ reduction in $\mathrm{HC}$ is observed by adding $\mathrm{CeO}_{2}$ nano particle to tested fuels at $23^{\circ} \mathrm{bTDC}$. The $\mathrm{CeO}_{2}$ acts as an oxidation catalyst and enhance the $\mathrm{HC}$ and provides the complete combustion. In addition, a significant reduction in $\mathrm{HC}$ emissions is observed at $23^{\circ} \mathrm{CA}$ bTDC. At retard IT $\left(23^{\circ} \mathrm{CA}\right.$ bTDC), there is the lesser quantity of fuel admittance which improves the atomisation process and combustion process and results in lower $\mathrm{HC}$ emissions. This result is in line with much other research works carried for nano particle additives with biodiesel (Jayaprabakar et al., 2015; Sabari et al., 2018).

\section{Carbon Monoxide (CO) Emission}

Figures $5 a, 5 b$ and $5 c$ show the variations in $\mathrm{CO}$ emission for palm biodiesel and diesel blends (BD20) doped with different proportions of $\mathrm{CeO}_{2}$ nano particles. The $\mathrm{CO}$ emissions from biodiesel and diesel blends are less than diesel at all loads (Venkata Ramanan and Yuvarajan, 2016). The CO emissions from all fuels increase with the load. At higher loads, the mixture becomes too rich causing higher $\mathrm{CO}$ emissions. Addition of $\mathrm{CeO}_{2}$ nano particle reduces $\mathrm{CO}$ emissions for tested fuels. This is due to the catalytic activity of $\mathrm{CeO}_{2}$ nano particle which aids the improved combustion. Further, the $\mathrm{CeO}_{2}$ nano particle provides surplus oxygen during combustion which in turn promotes the oxidation reaction (Ravichandra Ganesh and Hemachandra Reddy, 2015; Pandian et al., 2017). The $14 \%$ to $22 \%$ reduction in $\mathrm{CO}$ is observed for adding $\mathrm{CeO}_{2}(30$ $\mathrm{ppm}$ to $90 \mathrm{ppm}$ ) to tested fuels at $23^{\circ} \mathrm{bTDC}$. At retard IT $\left(23^{\circ} \mathrm{CA} \mathrm{bTDC}\right)$, there is the lesser quantity of fuel admittance which improves the atomisation process and combustion process and results in lower $\mathrm{CO}$ emissions. This result is in line with much other research works carried for nano particle additives with biodiesel (Jayaprabakar et al., 2015; Sabari et al., 2018; Venkata Ramanan and Yuvarajan, 2016).

\section{Nitrogen Oxides $\left(\mathrm{NO}_{x}\right)$ Emission}

Figures $6 a, 6 b$ and $6 c$ show the variations in $\mathrm{NO}_{x}$ emissions for palm biodiesel and diesel blends (BD20) doped with different proportions of $\mathrm{CeO}_{2}$ nano particles. The $\mathrm{NO}_{x}$ formation is attributed to three main factors namely, high combustion temperature, the presence of an excess of oxygen and the chemical kinetic rate. The $\mathrm{NO}_{x}$ for $\mathrm{BD} 20$ is higher than diesel at all loads owing to the higher inbuilt oxygen content in fuel and high temperature during combustion 
(a)

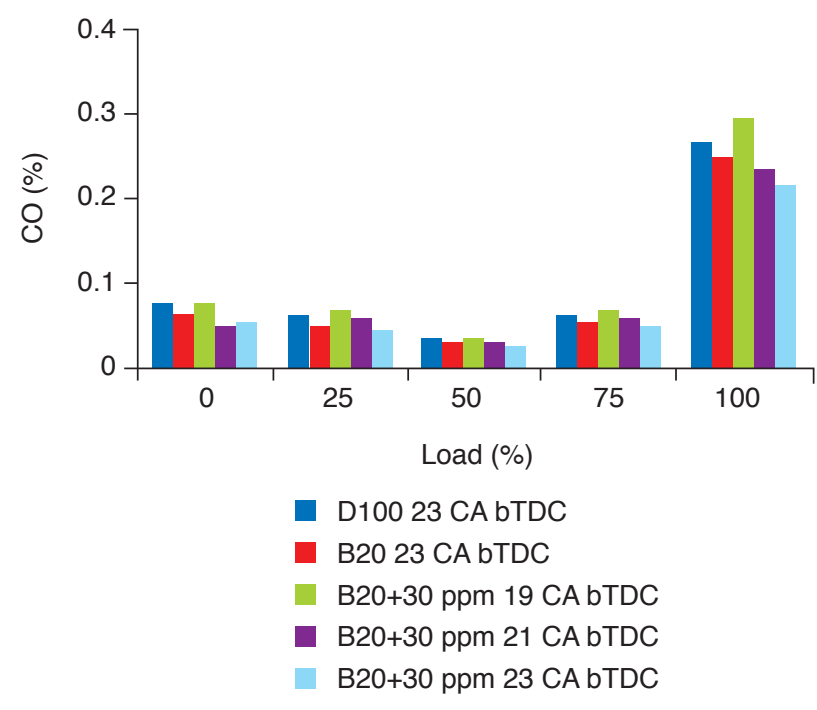

(b)

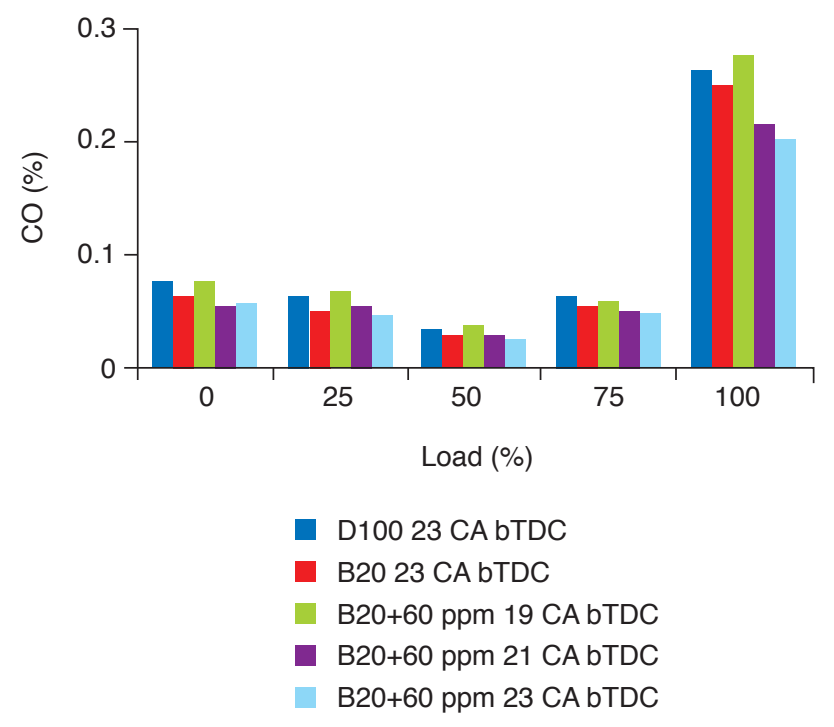

(c)

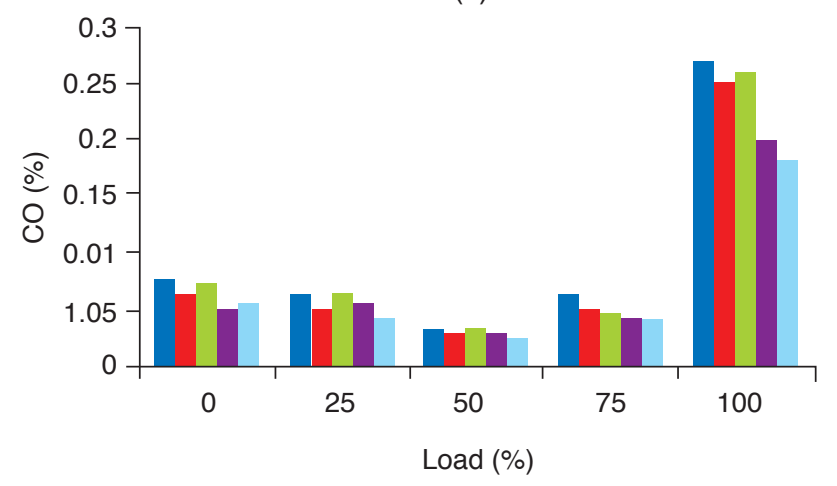

D100 23 CA bTDC
B20 23 CA bTDC
B20+90 ppm 19 CA bTDC
B20+90 ppm 21 CA bTDC
B20+90 ppm 23 CA bTDC

Figure 5. Carbon monoxide (CO) emissions of palm biodiesel and diesel blends at different working conditions $(a, b, c)$. (a)

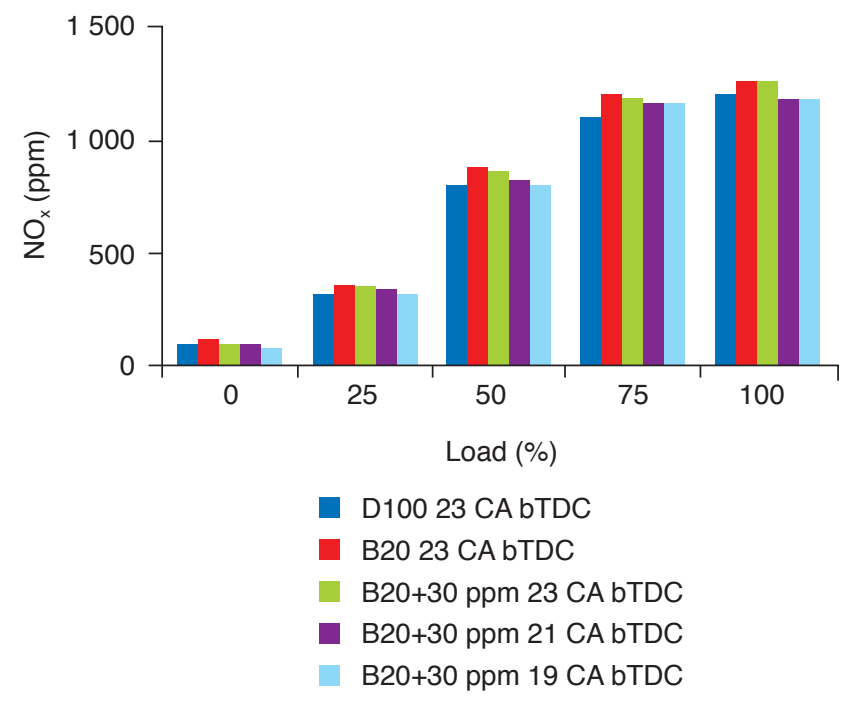

(b)

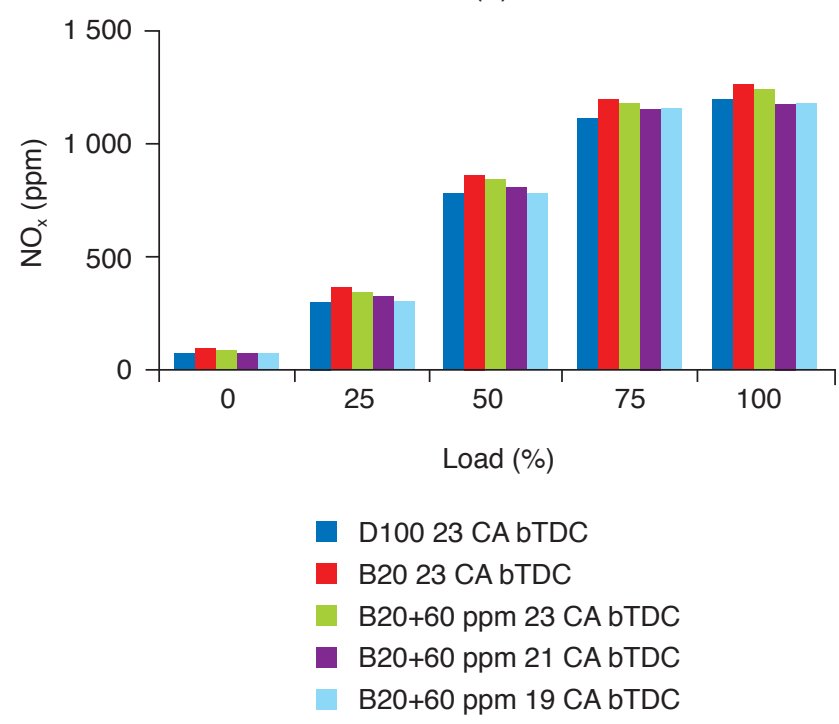

(c)

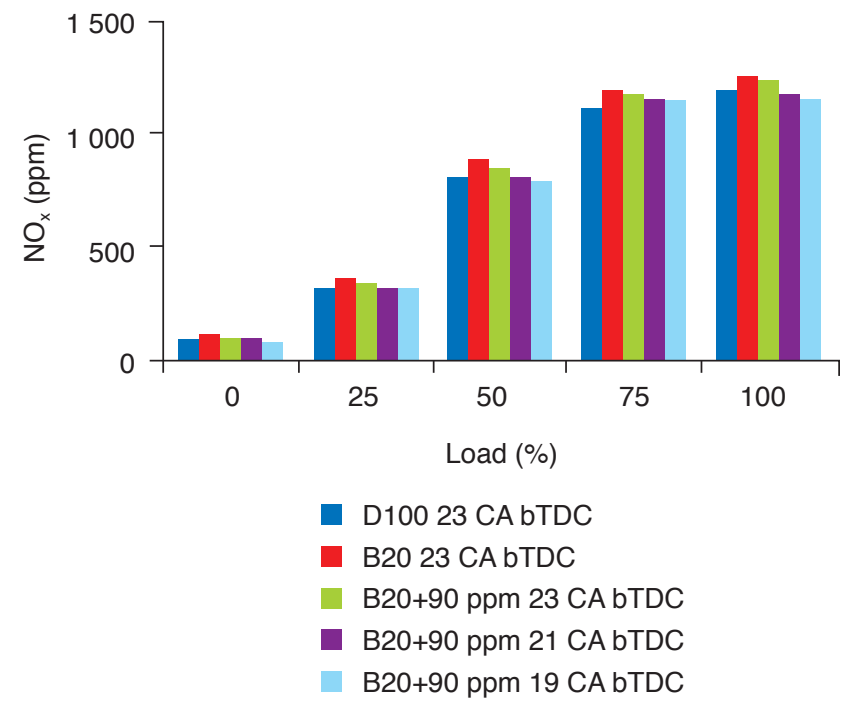

Figure 6. The nitrogen oxide $\left(\mathrm{NO}_{X}\right)$ emissions of palm biodiesel and diesel blends at different working conditions ( $a, b$ and $c)$. 
inside the combustion chamber (Yuvarajan et al., 2017; Sabari et al., 2018; Jayaprabakar et al., 2017). The $\mathrm{NO}_{x}$ emissions for tested fuels increase with the load. At higher loads, the temperature during combustion becomes higher causing higher $\mathrm{NO}_{\mathrm{x}}$ emissions. The addition of $\mathrm{CeO}_{2}$ nano particle reduces $\mathrm{NO}_{\mathrm{x}}$ emissions for tested fuels. This is due to the catalytic activity of $\mathrm{CeO}_{2}$ nano particle which aids the improved combustion. Further, the $\mathrm{CeO}_{2}$ nano particle provides surplus oxygen during combustion which in turn promotes the oxidation reaction (Ravichandra Ganesh and Hemachandra Reddy, 2015; Pandian et al., 2017). The $\mathrm{CeO}_{2}$ nano particle increases the effective surface area due to inbuilt oxygen and accelerates the oxidation reaction and lower $\mathrm{NO}_{\mathrm{x}}$ emission. This result is in line with much other research works carried for nano particle additives with biodiesel (Ravichandra Ganesh and Hemachandra Reddy, 2015; Pandian et al., 2017). The $8 \%$ to $12 \%$ reduction in $\mathrm{NO}_{\mathrm{x}}$ is observed for adding $\mathrm{CeO}_{2}$ (30 ppm to $90 \mathrm{ppm}$ ) to BD20 at $23^{\circ} \mathrm{bTDC}$. At retard IT $\left(23^{\circ} \mathrm{CA} \mathrm{bTDC}\right)$, there is the lesser quantity of fuel admittance which improves the atomisation process and combustion process and results in lower combustion temperature and lowers $\mathrm{NO}_{x}$ emissions. This result is in line with much other research works carried for nano particle additives with biodiesel (Jayaprabakar et al., 2015; Sabari et al., 2018; Venkata Ramanan and Yuvarajan, 2016).

\section{CONCLUSION}

The intention of this experimental work is to observe the effect of IT $\left(19^{\circ}, 21^{\circ}\right.$ and $\left.23^{\circ}\right)$ on cerium oxide nano particle doped palm biodiesel and diesel blends. A four-stroke, vertical, air-cooled, single cylinder, diesel engine is operated using test fuels. The results obtained are compared with petroleum diesel and the major conclusions drawn from this work is detailed as follows;

- $\quad$ palm biodiesel can be blended with diesel;

- $\mathrm{CeO}_{2}$ nano particle doped palm biodiesel and diesel blends showed better-quality performance than neat blends;

- HC and CO emissions for palm biodiesel and diesel blends are lesser than diesel at all working conditions owing to its oxidation capability and the catalytic effect; and

- $\mathrm{NO}_{\mathrm{x}}$ emissions for palm biodiesel and diesel blends are higher than diesel at all working conditions. However, $\mathrm{NO}_{\mathrm{x}}$ emissions decreased with retard IT $\left(\mathrm{IT}=23^{\circ} \mathrm{bTDC}\right)$.

\section{REFERENCES}

DEVARAJAN, Y; JAYABAL, R KUMAR; RAGUPATHY, D and VENU, H (2016). Emissions analysis on second generation biodiesel. Frontiers Environ. Sci. Eng., 11(1): 3.

DEVARAJAN, Y; NAGAPPAN, B $\mathrm{K}$ and MUNUSWAMY, D B (2017a). Performance and emissions analysis on diesel engine fuelled with cashew nut shell biodiesel and pentanol blends. Korean J. Chem. Eng., 344: 1021-1026.

DEVARAJAN, Y; MUNUSWAMY, D B and MAHALINGAM, A (2017b). Performance, combustion and emission analysis on the effect of ferrofluid on neat biodiesel. Process Saf. Environ. Prot., 111: 283-291.

JAYAPRABAKAR, J; DEY, B; DEY, K; HAREESH, $B$ and ANISH, M (2017). Optimization of rice bran biodiesel blends on $\mathrm{CI}$ engine and investigating its effects. IOP Conference Series: Materials Science and Engineering, 197: 012016. DOI:10.1088/1757$899 x / 197 / 1 / 012016$.

JAYAPRABAKAR, J; KARTHIKEYAN, A and RAMESHKUMAR V (2015). Effect of injection timing on the combustion characteristics of rice bran and algae biodiesel blends in a compressionignition engine. I. J. Ambient Energy, 38(2): 116-121. DOI:10.1080/01430750.2015.1048901.

KARTHIKEYAN, A and JAYAPRABAKAR, J (2017). Energy and exergy analysis of compression ignition engine fuelled with rice bran biodiesel blends. I. J. Ambient Energy: 1-7. DOI:10.1080/01430750.2017.13 99459.

MURUGESAN, A; SUBRAMANIAM, D; AVINASH, A and NEDUNCHEZHIAN, N (2013). Quantitative and qualitative analysis of biodiesel - An in-depth study. I. J. Ambient Energy, 36(1): 19-30.

NAIK, N S and BALAKRISHNA, B (2017). A comparative study of B10 biodiesel blends and its performance and combustion characteristics. I. J. Ambient Energy: 257-263. DOI:10.1080/01430750.20 17.1303629 .

PANDIAN, A K; RAMAKRISHNAN, R B B; and DEVARAJAN, Y (2017). Emission analysis on the effect of nanoparticles on neat biodiesel in unmodified diesel engine. Envi. Science Pollution Res, 24(29): 23273-23278. DOI:10.1007/s11356-0179973-6.

RAJ BUKKARAPU, K (2017). Comparative study of different biodiesel-diesel blends. I. J. Ambient Energy: 1-9. DOI:10.1080/01430750.2017.1393775.

RAVICHANDRA GANESH, P and HEMACHANDRA REDDY, K (2015). Experimental investigation on the performance and emission 
characteristics of di-diesel engine using dieselethanol blends with aqueous cerium oxide nanofluid as additive. Appl Mech. Mater. 787: 741745. DOI:10.4028/www.scientific.net/amm.787.741.

SABARI GIRISH, G; VIJAYAKOTHANDARAMAN, $\mathrm{R}$ and PRABHU, A (2018). Experimental investigation on a CI engine fuelled with bio gas and rice straw additives. I. J. Ambient Energy: 1-3. DOI:10.1080/014 30750.2017.1423388.

SAJEEVAN, A C and SAJITH, V (2016). Synthesis of stable cerium zirconium oxide nanoparticle Diesel suspension and investigation of its effects on diesel properties and smoke. Fuel, 183: 155-163. DOI:10.1016/j.fuel.2016.06.048.

VENKATA RAMANAN, $\mathrm{M}$ and YUVARAJAN, D (2016). Emission analysis on the influence of magnetite nanofluid on methyl ester in diesel engine.
Atmos. Pollu. Res, 7(3): 477-481. DOI:10.1016/j. apr.2015.12.001.

YILMAZ, N and ATMANLI, A 2017. Experimental assessment of a diesel engine fueled with dieselbiodiesel-1-pentanol blends. Fuel, 191: 190-197.

YUVARAJAN, D; DINESH BABU, M; BEEMKUMAR, N and AMITH KISHORE, P (2017). Experimental investigation on the influence of titanium dioxide nanofluid on emission pattern of biodiesel in a diesel engine. Atmos Pollu Res., 9(1): 47 - 52. DOI:10.1016/j.apr.2017.06.003.

YUVARAJAN, D; RAVIKUMAR, J and BABU, M D (2016). Simultaneous optimization of smoke and NOx emissions in a stationary diesel engine fuelled with diesel-oxygenate blends using the grey relational analysis in the Taguchi method. Anal. Methods, 832: 6222-6230. 